\title{
EFFECTS OF PROGESTERONE ON THE FATE OF BLASTOCYSTS IN RATS HYPOPHYSECTOMIZED ON THE FIRST DAY OF PREGNANCY
}

\author{
J. T. WU,* Z. DIGKMANN AND D C. JOHNSON \\ Departments of Obstetrics and Gynecology, and Physiology, \\ University of Kansas Medical Center, Kansas City, Kansas 66103, U.S.A.
}

(Received 23rd Fune 1971, accepted 7th October 1971)

\begin{abstract}
Summary. The beneficial effect of progesterone on blastocyst survival in the uterus was shown in rats hypophysectomized on Day 1 of pregnancy. Treatment with progesterone $(2 \mathrm{mg} /$ day $)$ on Day 1 , Day 1 and Day 6, or Days 1 to 5 could maintain most blastocysts for only 5 days following the last injection; during the next 5 days, many disintegrated in the uterus. Daily injections of $2 \mathrm{mg}$ progesterone, however, could maintain most blastocysts for as long as Day 53.

In hypophysectomized rats, the developmental potential of blastocysts deteriorated rapidly even though the rats received $2 \mathrm{mg}$ progesterone daily. By Day 20 , only $23 \%$ of blastocysts were capable of developing into full-term fetuses compared with $52 \%$ in rats ovariectomized on Day 4 and injected daily with $2 \mathrm{mg}$ progesterone. By Day 52 , none of the blastocysts from either group of animals developed to term although many still retained the ability to implant.
\end{abstract}

\section{INTRODUCTION}

In rats hypophysectomized on Day 1 of pregnancy (the day of finding spermatozoa in the vagina), the majority of fertilized eggs are expelled from the uterus between Days 5 and 6 (Wu, Dickmann \& Johnson, 1971a). This expulsion can be effectively prevented by a single injection of $2 \mathrm{mg}$ progesterone on Day 1 (Wu, Dickmann \& Johnson, 1971b).

The objective of the present study was to determine the survival and developmental potential of blastocysts in rats hypophysectomized on Day 1 of pregnancy and treated with various regimens of progesterone.

Previous studies were designed to determine the embryonic potential of blastocysts in ovariectomized, progesterone-treated rats (Canivenc \& Laffargue, 1957; Cochrane \& Meyer, 1957; Meyer \& Nutting, 1964; Buchanan, 1969). However, in these studies, the end point was the blastocyst's ability to implant, which is an inadequate criterion for developmental potential because, as our results will show, the blastocyst's ability to implant is not necessarily an indication for its ability to develop into a full-term fetus. The present hypophy-

* Present address: Worcester Foundation for Experimental Biology, Shrewsbury, Massachusetts 01545, U.S.A. 
sectomy approach offers an additional advantage in that there are no surgical complications with the oviducts, as can occur with ovariectomy, especially when it is performed as early as Day 1 (Wu \& Dickmann, 1971).

\section{MATERIALS AND METHODS}

Young, adult, virgin female rats of Holtzman strain, weighing 180 to $200 \mathrm{~g}$, were caged in air-conditioned quarters in which the lights were on from 06.00 to 20.00 hours. The females were placed with male breeders on the day of pro-oestrus and examined the next morning for the presence of spermatozoa in the vagina (Day 1 of pregnancy). Mated females were hypophysectomized between 09.30 and 10.30 hours on Day 1 . They were then provided with $5 \%$ glucose in the drinking water. Completeness of hypophysectomy was carefully checked at the time of autopsy.

TABLE 1

EGG RECOVERY IN HYPOPHYSECTOMIZED OR OVARIECTOMIZED RATS TREATED WITH PROGESTERONE

\begin{tabular}{|c|c|c|c|c|c|}
\hline \multirow[b]{2}{*}{ Group } & \multicolumn{2}{|r|}{ Treatment } & \multirow{2}{*}{$\begin{array}{c}\text { Rats } \\
\text { killed } \\
\text { on Day }\end{array}$} & \multirow{2}{*}{$\begin{array}{l}\text { No. of } \\
\text { rats }\end{array}$} & \multirow{2}{*}{$\begin{array}{l}\text { Average no. of } \\
\text { blastocysts/ } \\
\text { rat } \pm \text { S.E. } *\end{array}$} \\
\hline & Surgery & $\begin{array}{c}2 \mathrm{mg} \text { progesterone } \\
\text { on Day }\end{array}$ & & & \\
\hline $\begin{array}{r}1 \\
2 \\
3 \\
4 \\
5 \\
6 \\
7 \\
8 \\
9 \\
10 \\
11 \\
12\end{array}$ & $\begin{array}{l}\text { AP } \\
\text { AP } \\
\text { AP } \\
\text { AP } \\
\text { AP } \\
\text { AP } \\
\text { AP } \\
\text { AP } \\
\text { AP } \\
\text { OV } \\
\text { OV } \\
\text { OV }\end{array}$ & $\begin{array}{l}1 \\
1+ \\
1+U L \\
1,6 \\
1 \text { to } 5 \\
1 \text { to } 5 \\
1 \text { to } 19 \\
1 \text { to } 31 \\
1 \text { to } 51 \\
4 \text { to } 19 \\
4 \text { to } 31 \\
4 \text { to } 51\end{array}$ & $\begin{array}{r}6 \\
10 \\
10 \\
10 \\
10 \\
15 \\
20 \\
32 \\
52 \\
20 \\
32 \\
52\end{array}$ & $\begin{aligned} 10(0) \dagger \\
8(3) \\
10(3) \\
11(2) \\
6(0) \\
7(0) \\
10(0) \\
18(1) \\
13(2) \\
12(1) \\
11(2) \\
9(2)\end{aligned}$ & $\begin{array}{r}8.0 \pm 1.0 \\
2.8 \pm 0.9 \\
2.7 \pm 0.9 \\
6.6 \pm 0.8 \\
10.3 \pm 0.9 \\
4.1 \pm 0.9 \\
11.2 \pm 0.6 \\
9.2 \pm 0.7 \\
8.4 \pm 0.6 \\
8.5 \pm 0.6 \\
6.9 \pm 1.0 \\
8.4 \pm 1.4\end{array}$ \\
\hline
\end{tabular}

$\mathrm{UL}=$ Uterine ligature on the morning of Day 5. AP = Hypophysectomy on Day 1 of pregnancy. OV = Ovariectomy on Day 4 of pregnancy.

* Excluding the rats with no eggs.

$\dagger$ The number of rats with no eggs in parentheses.

To determine the effect of progesterone on blastocyst survival in the uterus, six groups of rats (Groups 1 to 6, Table 1) were injected subcutaneously with $2 \mathrm{mg}$ progesterone (in $0.1 \mathrm{ml}$ sesame oil) on Day 1, Day 1 and Day 6, or Days 1 to 5 , and were killed between 09.20 and 11.20 hours on Days 6, 10 or 15. The uteri were excised and flushed with $0.9 \% \mathrm{NaCl}$ solution. The washings were examined with a dissecting microscope $(\times 40)$ for the presence of eggs.

Three groups of rats (Groups 7 to 9) were used to study the long-term survival of blastocysts in hypophysectomized rats treated daily with $2 \mathrm{mg}$ progesterone. These rats were killed between 14.00 and 16.20 hours on Days 20, 32 or 52 . The uteri were flushed with medium consisting of one part of rat serum and two parts of $0.9 \% \mathrm{NaCl}$. All blastocysts recovered from a rat, irrespective of their morphological appearances, were transferred into the uteri of recipient rats 
(for details, Wu et al., 1971a) on Day 4 of pseudopregnancy (Day 1 = cervical stimulation on the day of oestrus). The recipients were killed on Day 19 of pseudopregnancy (i.e. 15 days after transfer of blastocysts) and the number of live fetuses and resorption sites were recorded.

\section{RESULTS}

Effect of progesterone on blastocyst survival

In rats hypophysectomized and injected with $2 \mathrm{mg}$ of progesterone on Day 1 of pregnancy, the average number of blastocysts recovered decreased significantly $(P<0.01$ ) from $8.0 \pm 1.0$ on Day 6 (Group 1, Table 1) to $2.8 \pm 0.9$ on Day 10 (Group 2). To test whether this reduction in the number of blastocysts

TABLE 2

DEVELOPMENTAL POTENTIAL OF BLASTOCYSTS RECOVERED FROM HYPOPHYSECTOMIZED OR OVARIECTOMIZED DONOR RATS AND TREATED DAILY WITH PROGESTERONE*

\begin{tabular}{|c|c|c|c|c|c|c|c|}
\hline \multicolumn{4}{|c|}{ Blastocyst donor rats } & \multirow{2}{*}{$\begin{array}{c}\text { No. of } \\
\text { blastocysts } \\
\text { transferred }\end{array}$} & \multirow{2}{*}{$\begin{array}{l}\text { No. of } \\
\text { recipient } \\
\text { rats }\end{array}$} & \multirow{2}{*}{$\begin{array}{c}\text { No. of } \\
\text { fetuses } \\
\text { developed }\end{array}$} & \multirow{2}{*}{$\begin{array}{c}\text { No. of } \\
\text { resorption } \\
\text { sites }\end{array}$} \\
\hline Group & Surgery & $\begin{array}{l}\text { Killed } \\
\text { on Day }\end{array}$ & No. of rats & & & & \\
\hline $\begin{array}{r}7 \\
8 \\
9 \\
10 \\
11 \\
12\end{array}$ & $\begin{array}{l}\text { AP } \\
\text { AP } \\
\text { AP } \\
\text { OV } \\
\text { OV } \\
\text { OV }\end{array}$ & $\begin{array}{l}20 \\
32 \\
52 \\
20 \\
32 \\
52\end{array}$ & $\begin{array}{r}11 \\
11 \\
9 \\
11 \\
9 \\
5\end{array}$ & $\begin{array}{r}112 \\
95 \\
65 \\
88 \\
62 \\
49\end{array}$ & $\begin{array}{r}11 \\
10 \\
7 \\
10 \\
7 \\
5\end{array}$ & $\begin{array}{l}26(23 \%) \\
5(5 \%) \\
0 \\
46(52 \%) \\
5(8 \%) \\
0\end{array}$ & $\begin{array}{r}15(13 \%) \\
26(27 \%) \\
7(11 \%) \\
15(17 \%) \\
22(35 \%) \\
22(45 \%)\end{array}$ \\
\hline
\end{tabular}

$\mathrm{AP}=$ Hypophysectomy on Day $1 . \mathrm{OV}=$ Ovariectomy on Day 4.

* Progesterone, $2 \mathrm{mg} /$ day.

was caused by their disintegration in or their expulsion from the uterus, a ligature was placed at the cervical end of each uterus on the morning of Day 5 to prevent egg expulsion (Group 3). No increase in the number of blastocysts over Group 2 resulted, suggesting that the blastocysts disintegrated in utero. When $2 \mathrm{mg}$ of progesterone were injected on Day 6 in addition to Day 1 , $6.6 \pm 0.8$ blastocysts were recovered on Day 10 (Group 4), a significant increase over Group $2(P<0.01)$.

Daily injections of progesterone from Days 1 to 5 resulted in the recovery of an average of $10.3 \pm 0.9$ blastocysts on Day 10 (Group 5), which then decreased sharply $(P<0.001)$ to $4.1 \pm 0.9$ blastocysts on Day 15 (Group 6 ).

Effects of progesterone on long-term survival and developmental potential of blastocysts

Daily injections of $2 \mathrm{mg}$ progesterone resulted in the recovery of a full average complement of blastocysts $(11 \cdot 2 \pm 0 \cdot 6$ ) on Day 20 (Group 7, Table 1), $9 \cdot 2 \pm 0.7$ on Day 32 (Group 8) and $8 \cdot 4 \pm 0.6$ on Day 52 (Group 9). The majority $(95 \%)$ of the blastocysts looked normal, but their developmental potential dropped as they aged. Transfer of blastocysts recovered on Days 20, 32 and 52, yielded 23,5 and $0 \%$ full-term fetuses (Table 2). Of the nineteen blastocysts 
recovered on Day 10 (Group 3), seventeen were transferred to recipients wherein they yielded eight $(47 \%)$ fetuses.

At the time of completion of the experiments, it was learned that Weitlauf (1971) had just demonstrated the normal developmental potential $(35 \%)$ of blastocysts recovered on Day 30 from mice ovariectomized on the morning of Day 4 of pregnancy and injected daily with $2 \mathrm{mg}$ of progesterone. Consequently, a parallel study in the rat was performed, i.e. pregnant rats were ovariectomized on the morning of Day 4 and treated daily with $2 \mathrm{mg}$ progesterone. The average numbers of blastocysts recovered on Days 20,32 and 52 were $8 \cdot 5 \pm 0 \cdot 6,6 \cdot 9 \pm 1 \cdot 0$ and $8 \cdot 4 \pm 1 \cdot 4$, respectively (Groups 10,11 and 12 , Table 1 ); 52, 8 and $0 \%$, respectively, of these blastocysts developed into fetuses after transfer to recipients (Table 2).

\section{DISCUSSION}

In rats hypophysectomized on Day 1 of pregnancy, a single injection of $2 \mathrm{mg}$ progesterone on the same day was sufficient to prevent egg expulsion from the uterus up to Day 6 (Group 1; Wu et al., 1971b). However, without further progesterone treatment, an average of $5.2(65 \%)$ blastocysts disappeared from each rat between Days 6 and 10 (Group 2). The results of the ligature experiments (Group 3) suggest that the loss of blastocysts was caused by disintegration in utero. An additional injection of progesterone on Day 6 reduced significantly the loss of eggs (Group 4 versus 2); but this treatment was not as efficient as daily injections of progesterone during the first 5 days (Group 5 versus 4). However, with the latter treatment, $60 \%$ of blastocysts were lost between Days 10 and 15 (Group 5 versus 6). These experiments suggest that most blastocysts can survive in the uterus for at least 5 days following the last injection of progesterone, and that 60 to $65 \%$ of blastocysts disappear from the uteri during the next 5 days. Daily injections of progesterone maintained a high percentage of blastocysts up to Day 52 in both the hypophysectomized and the ovariectomized rats.

The reasons for the difference in developmental potential between Day-20 blastocysts recovered from the hypophysectomized and the ovariectomized rats $(23 \%$ versus $52 \%, P<0.001)$ may be that: (1) hypophysectomy was carried out on Day 1 and ovariectomy on Day 4 so that the uteri in the former group were under the sole influence of progesterone from Day 1 on, while those of the latter group were under the combined effects of endogenous oestrogen and progesterone up to Day 4 ; 2 ) the hypophysectomized rats were deficient in several metabolically important hormones, notably growth hormone, thyroid hormones and glucocorticoids, and therefore constantly losing weight. The importance of thyroid hormones in the maintenance of blastocysts has been suggested (Holland, Finley, Kazwell \& Meshberger, 1970); (3) the adrenals in the ovariectomized rats could secrete some ovarian steroids in response to elevated secretions of pituitary gonadotrophins.

Although an average of 8.4 blastocysts could be recovered from the uteri of the hypophysectomized and the ovariectomized rats on Day 52, none developed into a full-term fetus, in spite of their seemingly normal morphology. Buchanan 
(1969) has suggested that blastocysts remain 'viable' for as long as they survive (up to Day 19) in the ovariectomized rats receiving no progesterone treatment. However, his endpoint for viability was the presence of implantations which cannot be equated with the ability to develop into full-term fetuses. In the present study, $45 \%$ of the Day- 52 blastocysts from ovariectomized, progesteronetreated rats retained the ability to implant but none developed to full-term fetuses.

The developmental potential of Day-32 blastocysts from rats ovariectomized on Day 4 and injected daily with $2 \mathrm{mg}$ progesterone is much lower than that of Day-30 blastocysts (i.e. $8 \%$ versus $35 \%$ ) from similarly treated mice (Weitlauf, 1971). This could be due to a species difference or a difference in the relative progesterone dosage, considering the same $2-\mathrm{mg}$ dose in a $200-\mathrm{g}$ rat and in a 35-g mouse.

\section{AGKNOWLEDGMENTS}

This study was supported in part by a Population Council grant to Z.D. One of the authors (J.T.W.) was a Ford Foundation post-doctoral fellow in the Reproductive Physiology Program.

\section{REFERENCES}

Buchanan, G. D. (1969) Blastocyst survival in ovariectomized rats. F. Reprod. Fert. 19, 279.

Ganivenc, M. \& Laffargue, M. (1957) Survie des blastocystes de rat en l'absence d'hormones ovariennes. C. r. hebd. Séanc. Acad. Sci., Paris, 245, 1752.

Cochrane, R. L. \& Meyer, R. K. (1957) Delayed nidation in the rat induced by progesterone. Proc. Soc. exp. Biol. Med. 96, 155.

Holland, J. P., Finley, J. M., Kazwell, R. D. \& Meshberger, F. L. (1970) Progesterone-dependent blastocyst survival during altered thyroid activity in the rat. F. Reprod. Fert. 23, 143.

MEYER, R. K. \& NutTing, E. F. (1964) Effect of combinations of progesterone and oestrone on the delay of nidation, implantation and foetal survival in ovariectomized rats. F. Endocr. 29, 243.

WEITLAUf, H. M. (1971) Effect of progesterone on survival of blastocysts in uteri of ovariectomized mice. F. Endocr. 51, 375.

WU, J. T. \& Dickmann, Z. (1971) Unilateral ovariectomy during early pregnancy in rat: no effect on embryonic survival. Endocrinology, 88, 257.

Wu, J. T., Dickmann, Z. \& Johnson, D. C. (1971a) Effects of ovariectomy or hypophysectomy on day one of pregnancy on development and transport of fertilized rat eggs. F. Endocr. 49, 507.

Wu, J. T., Dickmann, Z. \& Johnson, D. C. (1971b) Effects of oestrogen and progesterone on the development, oviductal transport and uterine retention of eggs in hypophysectomized pregnant rats. F. Endocr. 51, 569. 